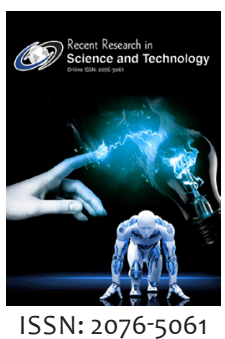

Received: December 11, 2019 Accepted: December 26, 2019 Published: December 31, 2019

*Corresponding Author: M. Cüneyt Bağdatli Email: cuneytbagdatli@ gmail.com

\section{Analysis of precipitation datas by mann kendall and sperman's rho rank correlation statistical approaches in Nevsehir province of Turkey}

\author{
M. Cüneyt Bağdatli' ${ }^{1 *}$ Esra Can ${ }^{2}$ \\ ${ }^{1}$ Nevsehir Haci Bektas Veli University, Engineering and Architecture Faculty, Department of Biosystem Engineering, \\ Nevsehir, Turkey, ${ }^{2}$ Nevsehir Haci Bektas Veli University, Institute of Science, Department of Environmental \\ Engineering, Nevsehir, Turkey
}

\begin{abstract}
In this research, the total and maximum precipitation values of long years (1970-2019) of Nevşehir province, Ürgüp districts and 34 years of Avanos 1986-2019 were subjected to the Mann Kendall and Sperman's Rho rank correlation tests. In this study; Change trends of the precipitation are presented with graphic distrubitions. According to the results of the trend analysis, it has been observed that the average maximum precipitation value for long years in Avanos district, Nevsehir Province and Ürgüp district is $9,1 \mathrm{~mm}, 11,3 \mathrm{~mm}, 10,7 \mathrm{~mm}$ and average total precipitation is $292,8 \mathrm{~mm}, 362,9 \mathrm{~mm}, 326,9 \mathrm{~mm}$ respectively. According to the results of maximum precipitation trends, it has been observed that there is a significant increase in Nevşehir province and Ürgüp districts in winter and autumn months. Considering the total precipitation distribution, it is concluded that there is a negative trend in the spring and autumn seasons in Nevşehir province and Ürgüp district.
\end{abstract}

KEYWORDS: Precipitation, mann kendall, sperman rho correlation, trend analysis, Nevsehir province of Turkey

\section{INTRODUCTION}

Turkey constitutes one of the risky countries can be experienced in the short or long-term climate variability [1]. The tendency of the global increase observed in the increase of temperatures does not show an equal distribution throughout the world. The prolonged warming tendency is higher between the $40^{\circ}$ and $70^{\circ}$ North latitudes. The greatest effects of climate change occur in countries located in middle and high latitudes [2]. The Central Anatolia Region is among the areas that will be affected by this change due to its geographical location [3]. Global climate change, which has increased the population and its impact in recent years, shows itself negatively in all areas. With the increase of carbon emissions in the air, the world has been threatened by climate change. Carbon is one of the basic elements of life when it is found in sufficient levels. However, when people consume more than they need, it causes serious $\mathrm{CO}_{2}$ in the atmosphere and decreases the protective effect of the ozone layer and causes irregularities in precipitation. It is known that the increase in carbon will increase over the years. With this increase, $\mathrm{CO}_{2}$ and greenhouse gases accumulated in the atmosphere descend to the earth with precipitation. This event is called acid rain. Acid rains change the $\mathrm{pH}$ of the water and affect the life of the living creatures in the water. It causes the natural structure of plants to deteriorate.

In this study, it was carried out to analyze the long-term total and maximum monthly precipitation values observed in the Nevsehir proivnce and Ürgüp district of Turkey between 19702019 (50 years), Avanos district between 1986-2019 (34 yaers) by trend analysis and to reveal the increase or decrease tendencies.

\section{MATERIAL AND METHOD}

The study area is located in the Nevsehir province of Turkey Located in the Central Anatolia region. In the study, the total and maximum rainfall values of the center and Ürgüp of the climate observation station of Avanos and Ürgüp districts, Nevsehir province belonging to the Turkish General Directorate of Meteorology between 1970-2019 and Avanos between 19862019 were used as materials in the study [4]. The location of the districts subject to the research are shown on the map given in Figure 1.

Copyright: $\odot$ The authors. This article is open access and licensed under the terms of the Creative Commons Attribution License (http://creativecommons.org/licenses/by/4.0/) which permits unrestricted, use, distribution and reproduction in any medium, or format for any purpose, even commercially provided the work is properly cited. Attribution - You must give appropriate credit, provide a link to the license, and indicate if changes were made. 
In the study, monthly changes in rainfall values observed in the meteorology stations of Avanos district, Nevsehir Province, Ürgüp district between 1970 and 2019 and Avanos between 1986 and 2019 were used. A total of 600 months were analyzed and the values obtained were statistically based on graphs and charts. In the study, it was subjected to total and maximum precipitation trend analysis for many years. In this sense, in order to evaluate the data, it was evaluated within the scope of Rho Kendall Test of Mann Kendall and Sperman and Trend Trend method of Sen and it was performed in the 95\% confidence level $[5,6]$. In the study, a software called "Trend Analysis for Windows", Mann-Kendall test, Spearman's Rho test, Mann-Kendall Order Correlation test and Sen's Trend Slope method are applied to the data and the result is given as graphics and text [7].

\section{RESEARCH RESULTS}

The trend analysis results regarding the maximum and total precipitation values between the Avanos and Ürgüp districts, Nevsehir Province and Ürgüp between 1970-2019 and between Avanos 1986-2019 are presented in detail below.

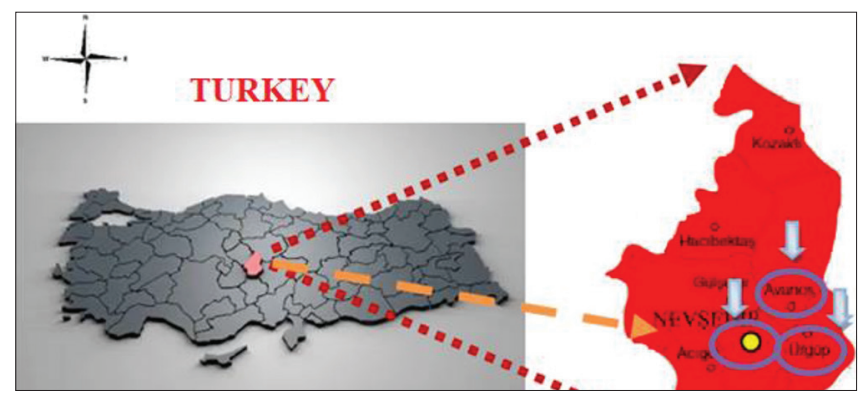

Figure 1: Location of the research area

\section{Maximum Precipitation Changes in Long Years}

For many years, maximum precipitation changes were evaluated on the basis of seasons and as general average and the results obtained were evaluated within the graphs presented below. The average maximum rainfall values for the spring months observed on the basis of many years are given in Figure 2 .

On the basis of maximum rainfall values in spring months, the maximum precipitation value was $21.0 \mathrm{~mm}$ in 2009, the lowest was $2.6 \mathrm{~mm}$ in $2019,11.0 \mathrm{~mm}$ in 2019 was the average. On the basis of maximum precipitation values in winter months, the maximum maximum precipitation value was observed in 1998 with $24.4 \mathrm{~mm}$, and the lowest average precipitation values in 2018 with the lowest $3.9 \mathrm{~mm}$ in 2018. On the basis of the maximum precipitation values in autumn months, the highest maximum precipitation value was $16.6 \mathrm{~mm}$ in 2014, the lowest was $1.6 \mathrm{~mm}$ and the average average of $9.0 \mathrm{~mm}$ in 2016 was observed. On the basis of the maximum precipitation values in the summer months, the highest maximum precipitation value was $22.5 \mathrm{~mm}$ in 2011, the lowest was $0.3 \mathrm{~mm}$ in 2003 and the average average of $7.4 \mathrm{~mm}$ in 2003 was observed. Considering the annual average values, it is seen that the highest value was $14.0 \mathrm{~mm}$ in 1998 and the lowest value was $3.0 \mathrm{~mm}$ and in 2018, the overall average value was $9.1 \mathrm{~mm}$. Trend analysis results of long-year maximum precipitation values observed in Nevşehir center are given in Figure 3.

According to this results; maximum rainfall values in the spring months, the maximum maximum precipitation value was $21.7 \mathrm{~mm}$ in 1994, the lowest average was $6.7 \mathrm{~mm}$ in 2018, and the maximum average of $14.0 \mathrm{~mm}$ in 2018 .

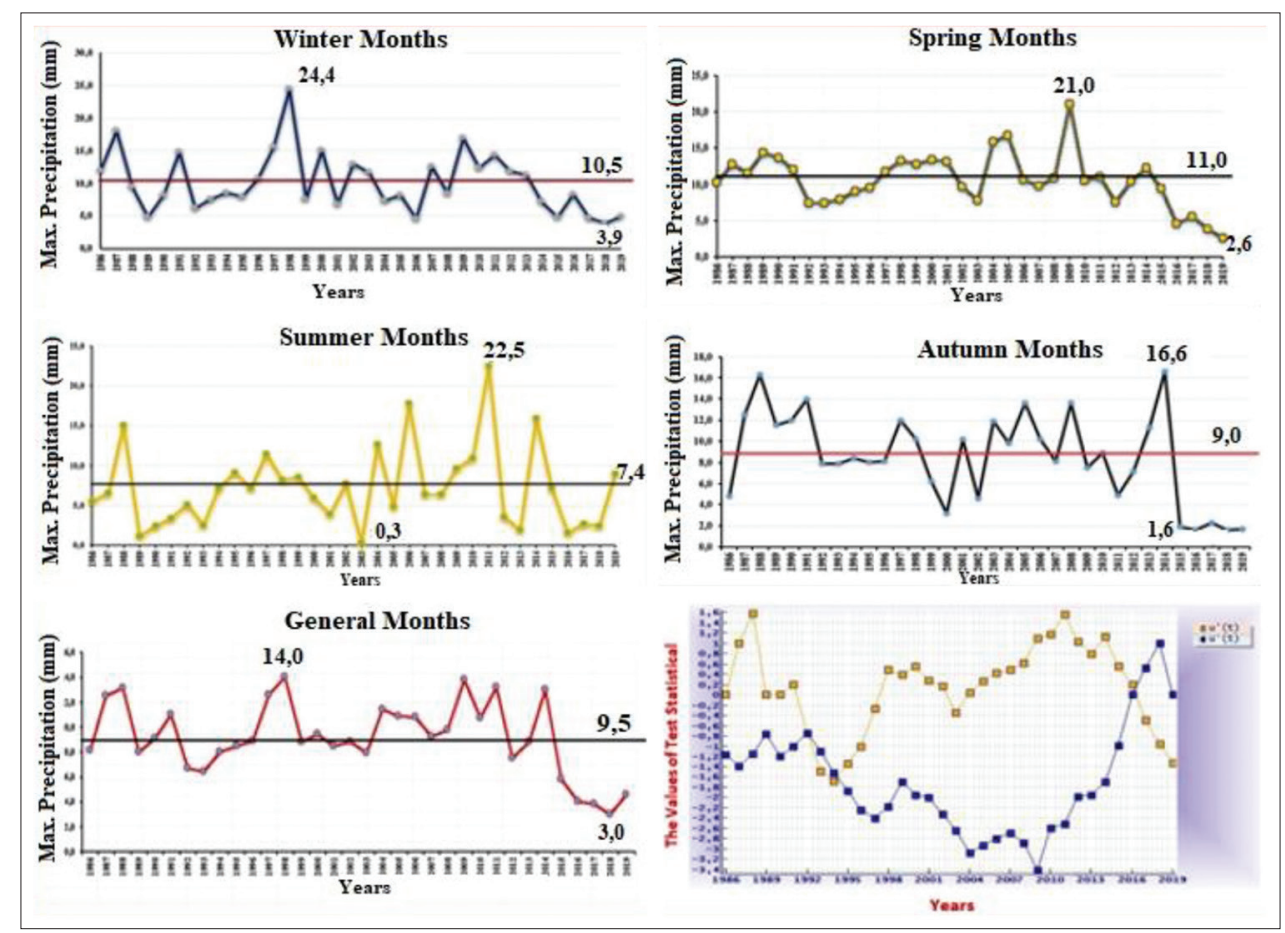

Figure 2: Maximum precipitation changes $(\mathrm{mm})$ of the avanos district in long periods 
The maximum precipitation values in winter months, the maximum maximum precipitation value was $24.3 \mathrm{~mm}$ in 1998, the lowest $4.8 \mathrm{~mm}$ in 1995 , and the average average of $12.7 \mathrm{~mm}$ in general was observed. On the basis of the maximum precipitation values in autumn months, the maximum maximum precipitation value was $20.9 \mathrm{~mm}$ in 1988, the lowest was $3.2 \mathrm{~mm}$ and the average average of $11.0 \mathrm{~mm}$ in 2019 was the average.

On the basis of the maximum precipitation values in the summer months, the highest maximum precipitation value was observed in 1872 and 1972, and the lowest average rainfall values in 7.7 with the lowest $0.1 \mathrm{~mm}$ in 2013. Considering the annual average values, it is seen that the highest value was $16.5 \mathrm{~mm}$ in 1987 and the lowest value was $5.8 \mathrm{~mm}$ and in 2018, the general average value was $11.3 \mathrm{~mm}$. Trend analysis results of long-year maximum precipitation values observed in Ürgüp district are given in Figure 4.

On the basis of maximum rainfall values in the spring months, the highest maximum precipitation value was observed in 1977 with $24.7 \mathrm{~mm}$, and the lowest average value of $13.4 \mathrm{~mm}$ in 1970 with the lowest $5.0 \mathrm{~mm}$. On the basis of maximum rainfall values in winter months, the maximum maximum precipitation value was $24.2 \mathrm{~mm}$ in 1998, the lowest was $4.1 \mathrm{~mm}$ and 1995, the average average of $11.0 \mathrm{~mm}$ in average was observed.

The maximum precipitation values in the summer months, the highest maximum precipitation value was $19.1 \mathrm{~mm}$, in 2006, the lowest was $1.1 \mathrm{~mm}$ and the average average of $7.5 \mathrm{~mm}$ in 2001 was observed. On the basis of the maximum precipitation values in autumn months, the highest maximum precipitation value was observed in 1983 with $26.2 \mathrm{~mm}$, and the lowest average of precipitation values was $10.8 \mathrm{~mm}$ in 1974 with the lowest $3.7 \mathrm{~mm}$.

The annual maximum average values, it is seen that the highest value is $16.0 \mathrm{~mm}$ and the lowest value is 1998 and the lowest average value is $5.7 \mathrm{~mm}$ in 2018 and the overall average value is $10.7 \mathrm{~mm}$. Table 1 . Trend analysis results of maximum rainfall values of Nevsehir province and Ürgüp, Avanos districts for many years were given in Table 1 .

According to the results of trend analysis of the maximum precipitation values of Nevşehir, Mann-Kendall Test shows that there is no trend in all four seasons, while Spearman's Rho Test shows that the trend groove in winter is not in other seasons and the general average is not.

The maximum precipitation values in Ürgüp district, it was observed that the Autumn season was a trend in the MannKendall Test, there was no trend in the Spearman's Rho Test, and in other seasons and the general average was not significant, both tests were observed. The results of trend analysis of Avanos maximum precipitation values, it was observed that there was no significant trend for both tests in general average and in four seasons in terms of overall average.

\section{Total Precipitation Changes in Long Years}

Total precipitation values for many years were analyzed in seasons and general average and all evaluations made in the

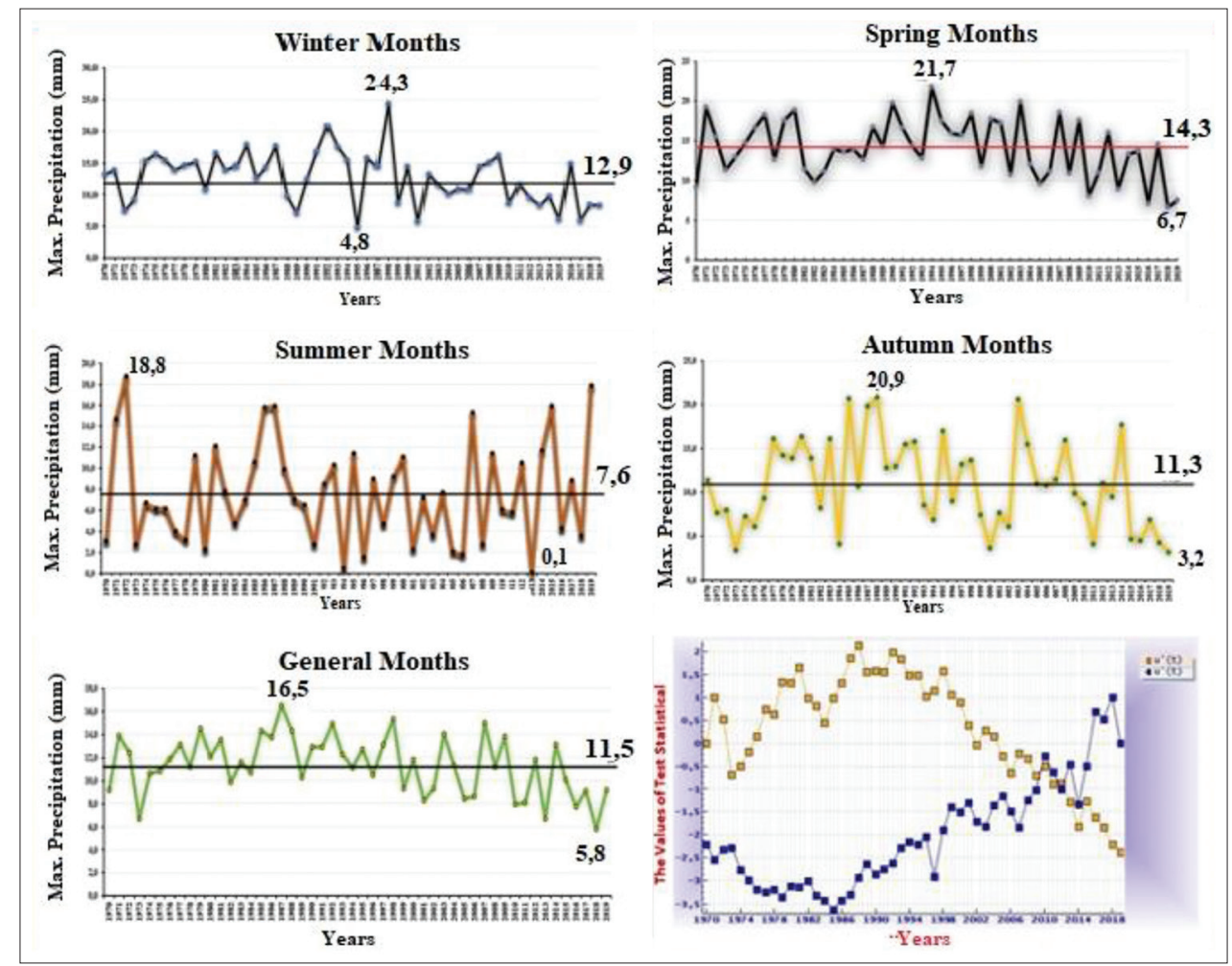

Figure 3: Maximum precipitation changes $(\mathrm{mm})$ of the nevsehir province in long periods 
Table 1: Trend analysis results of maximum rainfall values of Nevsehir province and Ürgüp, Avanos districts for many years

\begin{tabular}{|c|c|c|c|c|}
\hline Provinces & Years & Seasons & $\begin{array}{c}\text { Mann-Kendall } \\
\text { Test } \\
\text { Statistes } \\
\end{array}$ & $\begin{array}{l}\text { Spearman's } \\
\text { Rho Test } \\
\text { Statistics }\end{array}$ \\
\hline \multirow{5}{*}{ 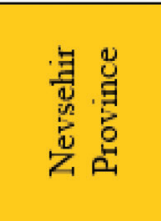 } & \multirow{5}{*}{ 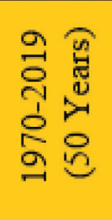 } & Spring Months & No Trend & No Trend \\
\hline & & Summer Months & No Trend & No Trend \\
\hline & & Autumn Months & No Trend & No Trend \\
\hline & & Winter Months & No Trend & Negative Trend \\
\hline & & General Average & No Trend & No Trend \\
\hline \multirow{5}{*}{ 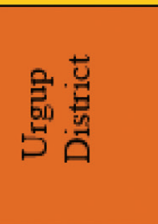 } & \multirow{5}{*}{ 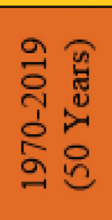 } & Spring Months & No Trend & No Trend \\
\hline & & Summer Months & No Trend & No Trend \\
\hline & & Autumn Months & Negative Trend & No Trend \\
\hline & & Winter Months & No Trend & No Trend \\
\hline & & General Average & No Trend & No Trend \\
\hline \multirow{5}{*}{ 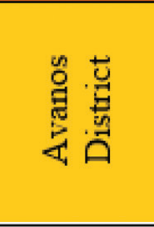 } & \multirow{5}{*}{ 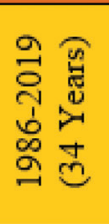 } & Spring Months & No Trend & No Trend \\
\hline & & Summer Months & No Trend & No Trend \\
\hline & & Autumn Months & No Trend & No Trend \\
\hline & & Winter Months & No Trend & No Trend \\
\hline & & General Average & No Trend & No Trend \\
\hline
\end{tabular}
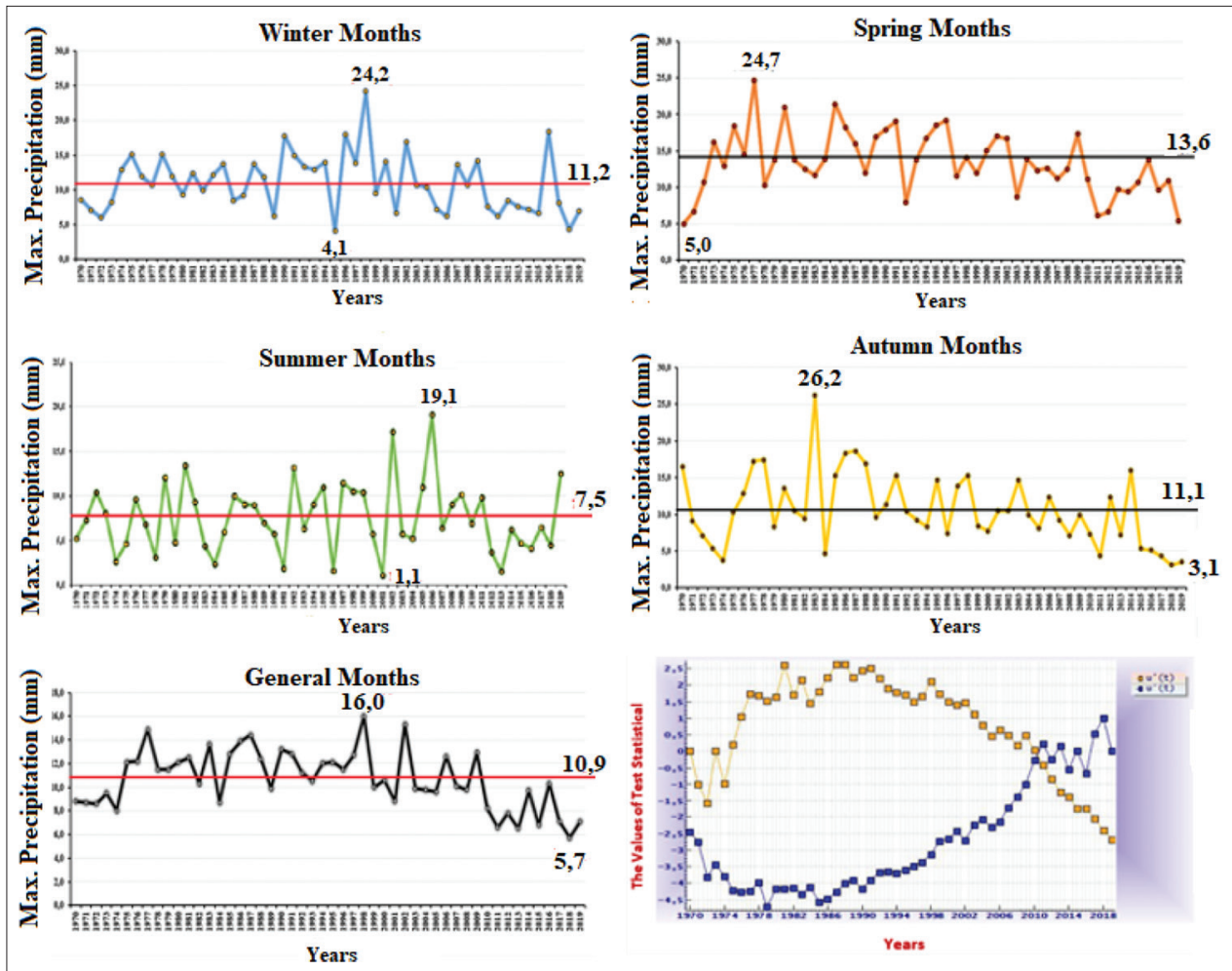

Figure 4: Maximum precipitation changes $(\mathrm{mm})$ of the Ürgüp district in long periods

light of the results obtained were presented graphically. Avanos District Total Precipitation Changes (mm) are given in Figure 5.

In the spring months, the total precipitation values were highest with the highest total precipitation value of $174.8 \mathrm{~mm}$ in 2009 and the lowest average of $102.3 \mathrm{~mm}$ in 2017 with the lowest of $36.3 \mathrm{~mm}$ in 2017. On the basis of total rainfall values in winter months, the highest total precipitation value was $184.2 \mathrm{~mm}$ in 2009 , the lowest was $35.5 \mathrm{~mm}$ in 2017, with an average of $96.1 \mathrm{~mm}$ in total average.

Total precipitation values in autumn months, the highest total precipitation value was $124.7 \mathrm{~mm}$ in 1988, the lowest $6.4 \mathrm{~mm}$ in 2019, and overall average of $62.1 \mathrm{~mm}$ in 2019. On the basis of total rainfall values in the summer months, the highest total 
precipitation value was $63.1 \mathrm{~mm}$ in 2019 , the lowest $6.4 \mathrm{~mm}$ in 2016, and overall average of $32.0 \mathrm{~mm}$ in 2016.

Considering the annual maximum average values, it is seen that the highest value was $481.8 \mathrm{~mm}$ and the lowest value in 2009 was $117.8 \mathrm{~mm}$ and the general average value in 2016 was $292.8 \mathrm{~mm}$. Nevsehir Total Rainfall Changes ( $\mathrm{mm})$ in long years are given in Figure 6.
The total precipitation values In the spring months were the highest with total precipitation value of $209.4 \mathrm{~mm}$ in 1995 , with the lowest of $63.7 \mathrm{~mm}$ in 2016, the overall average of $130.3 \mathrm{~mm}$ was observed. On the basis of total precipitation values in winter months, the highest total precipitation value was observed with an average of $123.5 \mathrm{~mm}$ in 1992, with the lowest average of $41.3 \mathrm{~mm}$ in 1992, and a total of $123.5 \mathrm{~mm}$ in 1995.

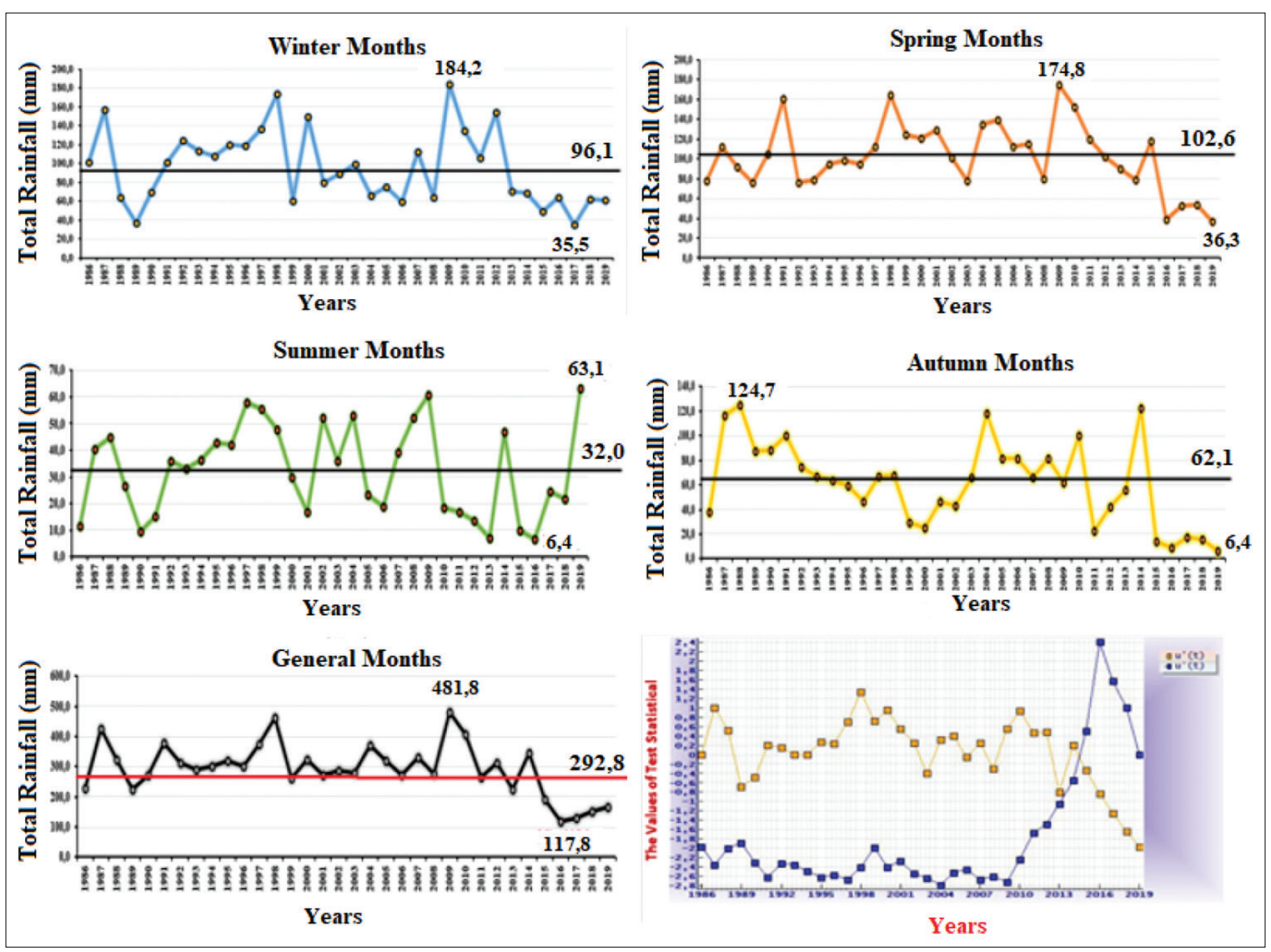

Figure 5: Total precipitation changes $(\mathrm{mm})$ of the avanos district in long periods

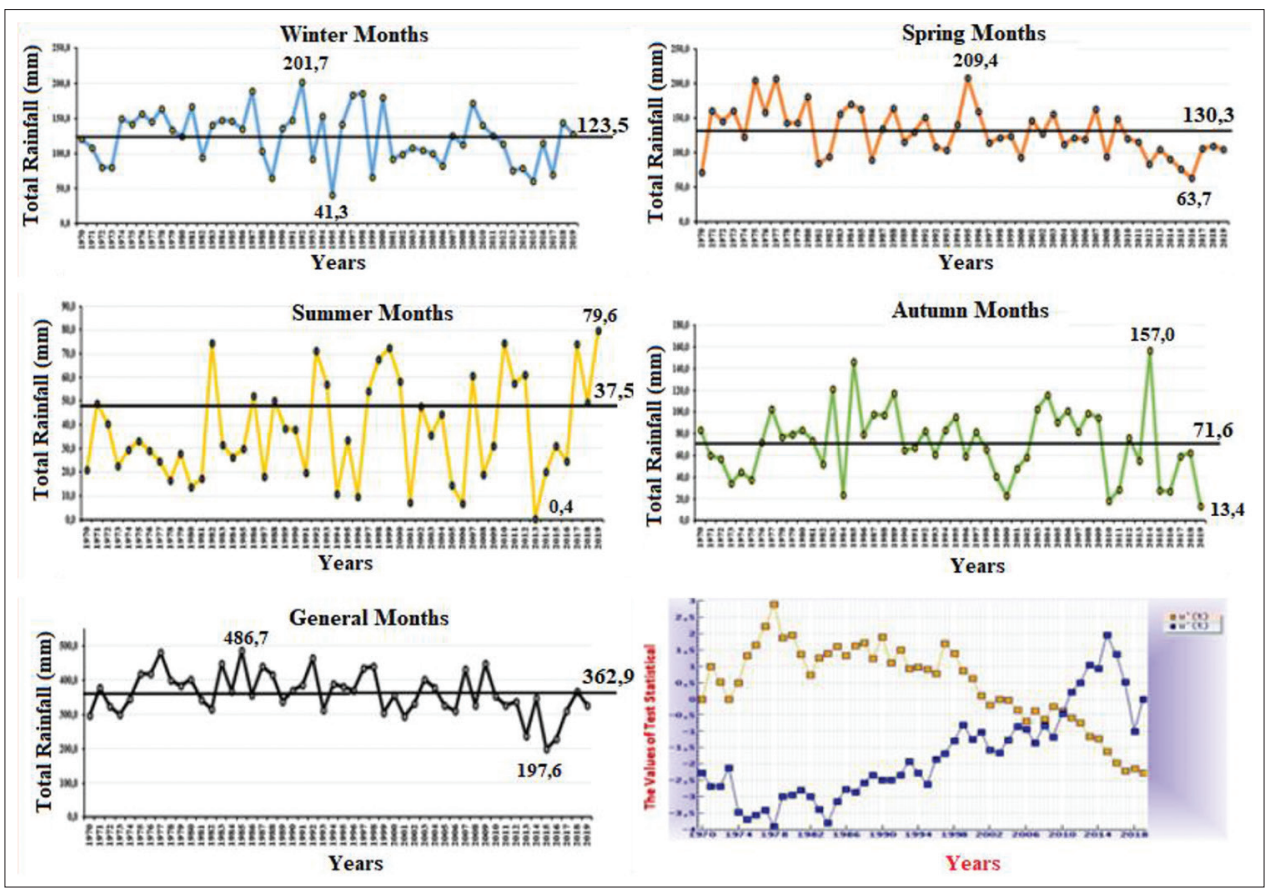

Figure 6: Total precipitation changes $(\mathrm{mm})$ of the nevsehir province in long periods 
Total precipitation values in autumn months, the highest total precipitation value was $157.0 \mathrm{~mm}$ in 2014, and the lowest was $13.4 \mathrm{~mm}$ in 2019, with an overall average of $71.6 \mathrm{~mm}$ in 2019. On the basis of total rainfall values in the summer months, the highest total precipitation value was $79.6 \mathrm{~mm}$ in 2019 , the lowest was $0.4 \mathrm{~mm}$ in 2013, and the overall average of $37.5 \mathrm{~mm}$ in 2013 was observed. Annual maximum average values, it is seen that the highest value was $486.7 \mathrm{~mm}$ in 1985 and the lowest value was $197.6 \mathrm{~mm}$ in 2015 and the general average value was 362.9. Total Rainfall Changes $(\mathrm{mm})$ in Ürgüp District for Long Years is given in Figure 7.
In the spring months, the total precipitation values were the highest with the total precipitation value of $195.6 \mathrm{~mm}$ in 1980, and the lowest with $70.6 \mathrm{~mm}$ in 2014, the overall average of $123.2 \mathrm{~mm}$ in average. On the basis of total precipitation values in winter months, the highest total precipitation value was found in 2000 with $159.4 \mathrm{~mm}$, and the lowest average of precipitation values was $95.9 \mathrm{~mm}$ in 1989 with the lowest of $44.2 \mathrm{~mm}$.

On the basis of total precipitation values in autumn months, the highest total precipitation value was found in 1987 with $169.6 \mathrm{~mm}$, and the lowest average of $14.5 \mathrm{~mm}$ in 2019 with a

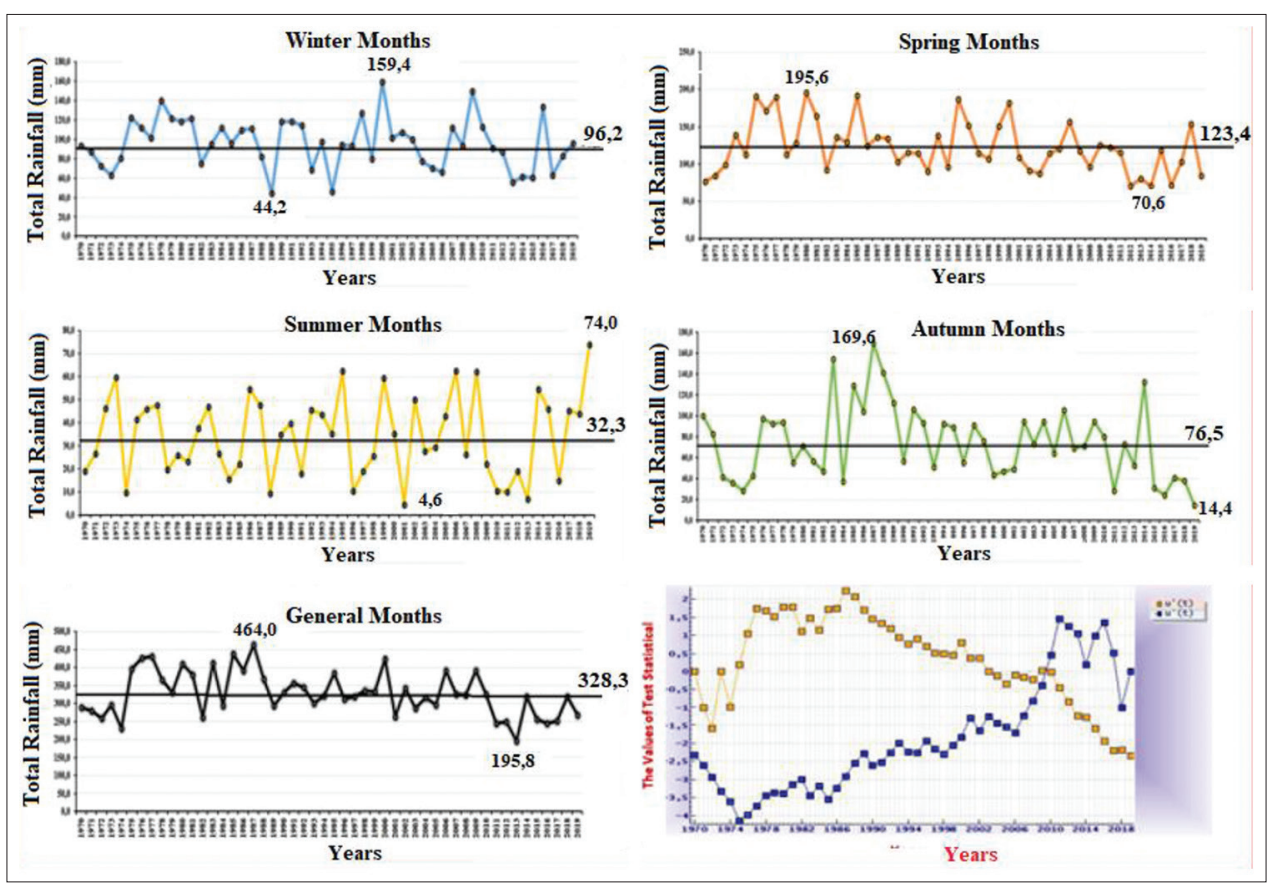

Figure 7: Total precipitation changes $(\mathrm{mm})$ of the nevsehir province in long periods

Table 2: Trend analysis results of total Precipitation values of Nevsehir province and Ürgüp, Avanos districts for many years

\begin{tabular}{|c|c|c|c|c|}
\hline Provinces & Years & Seasons & $\begin{array}{l}\text { Mann-Kendall } \\
\text { Test Statistics }\end{array}$ & $\begin{array}{c}\text { Spearman's Rho } \\
\text { Test Statistics }\end{array}$ \\
\hline \multirow{5}{*}{ 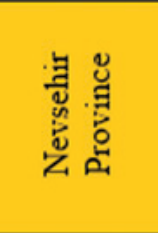 } & \multirow{5}{*}{ 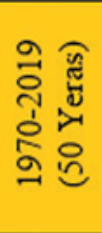 } & Spring Months & Negative Trend & Negative Trend \\
\hline & & Summer Months & No Trend & No Trend \\
\hline & & Autumn Months & No Trend & No Trend \\
\hline & & Winter Months & No Trend & No Trend \\
\hline & & General Average & Negative Trend & Negative Trend \\
\hline \multirow{5}{*}{ 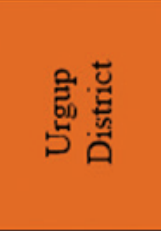 } & \multirow{5}{*}{ 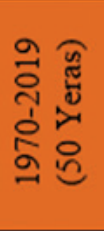 } & Spring Months & Negative Trend & Negative Trend \\
\hline & & Summer Months & No Trend & No Trend \\
\hline & & Autumn Months & No Trend & No Trend \\
\hline & & Winter Months & No Trend & No Trend \\
\hline & & General Average & Negative Trend & No Trend \\
\hline \multirow{5}{*}{ 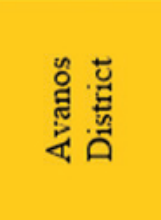 } & \multirow{5}{*}{ 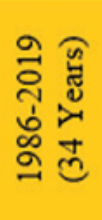 } & Spring Months & No Trend & No Trend \\
\hline & & Summer Months & No Trend & No Trend \\
\hline & & Autumn Months & Negative Trend & Negative Trend \\
\hline & & Winter Months & No Trend & No Trend \\
\hline & & General Average & No Trend & No Trend \\
\hline
\end{tabular}




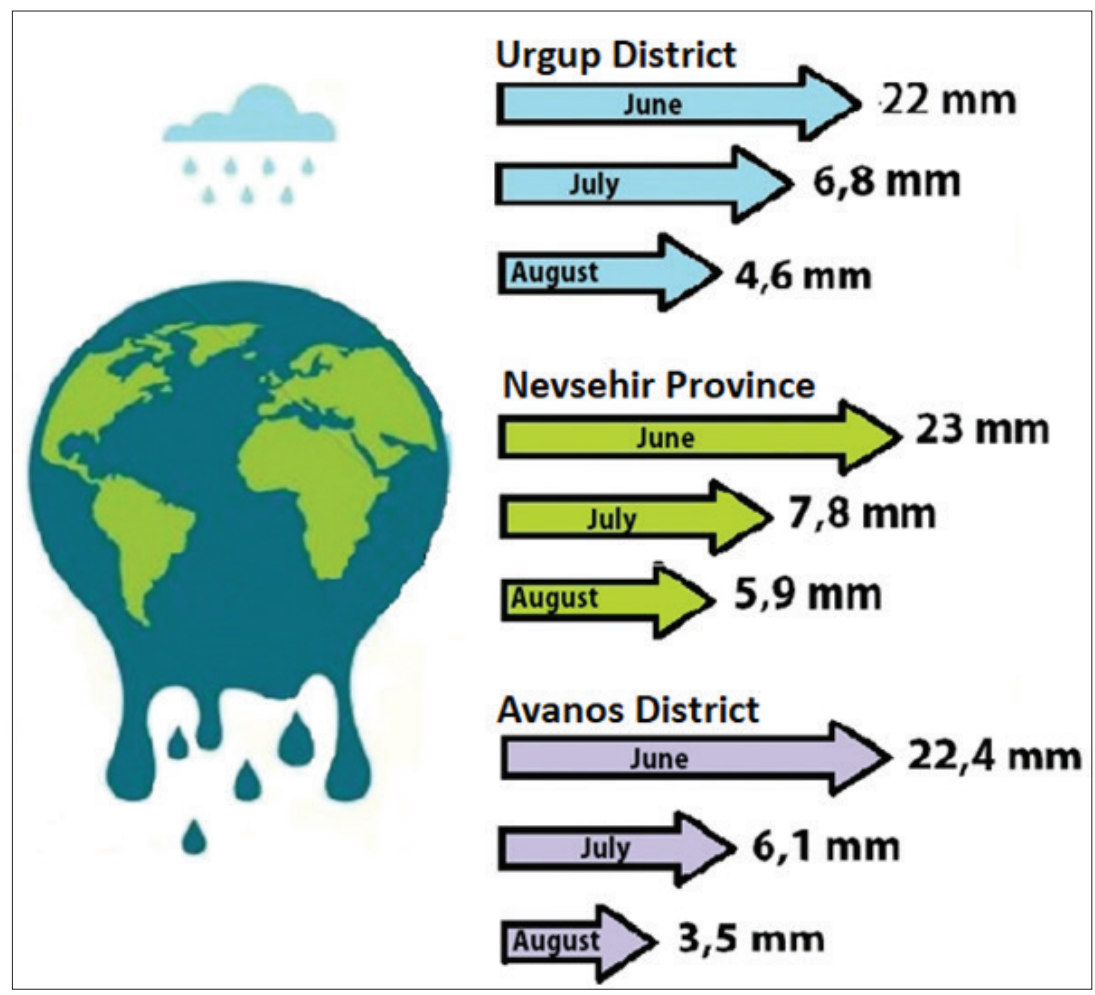

Figure 8: Summary distribution of all results for total precipitation over long period in summer months

total average of $74.5 \mathrm{~mm}$. On the basis of total rainfall values in the summer months, the highest total precipitation value was $74.0 \mathrm{~mm}$ in 2019, while the lowest was $4.6 \mathrm{~mm}$ in 2001, with an overall average of $33.4 \mathrm{~mm}$.

Annual maximum average values, it is seen that the highest value was $464.0 \mathrm{~mm}$ and the lowest value was 1998, while the overall average value was $326.9 \mathrm{~mm}$ in $195.8 \mathrm{~mm}$. Trend analysis results of total precipitation values of Nevşehir, Ürgüp, Avanos districts for long years are given in Table 2.

According to the trend analysis results of the total precipitation values of Nevşehir, when Mann-Kendall Test and Spearman's Rho Test, Spring season and general average trends are analyzed, it is seen that there are trends in both tests and there is no trend in other seasons. Considering the trend analysis results of Ürgüp maximum precipitation values, it is seen that both tests are the trend of Spring Season Kendall Test and Spearman's Rho Test. Looking at the general average trends, it is concluded that there is a trend in the Mann-Kendall Test and there is no trend in Spearman's Rho Test, and it is seen that there is no trend in both seasons in both tests. The trend analysis of Avanos maximum precipitation values, it is seen that there is a trend in both seasons for both tests in four seasons and there is no significant trend in general average values in other seasons.

\section{CONCLUSION AND SUGGESTIONS}

In this study, in which the total and maximum rainfall values were evaluated for a total of 50 years and 600 months, Avanos 1986-2019 (34 years) and 408 months between 1970 and 1919, in terms of long years, no increase or decrease trend was observed in precipitation values. A summary schematic image showing the distribution of total precipitation changes in the summer months is given in Figure 8.

Looking at Figure 8, when the precipitation amounts in June, the rainfalls in July and August decrease gradually due to the climate characteristics. The general average of summer months in Nevşehir is $20 \mathrm{~mm}$. In this context, while June is above average, the total precipitation values in July and August are far below average. Looking at the precipitation values; The longterm maximum precipitation averages of Avanos have been determined as $11.0 \mathrm{~mm}$ for the spring months, $10.5 \mathrm{~mm}$ for the winter months, $9.0 \mathrm{~mm}$ for the autumn months, $7.4 \mathrm{~mm}$ for the summer months and the general average is $9.1 \mathrm{~mm}$. Long-term maximum precipitation averages of Nevşehir are determined as $14.0 \mathrm{~mm}$ for spring months, $12.7 \mathrm{~mm}$ for winter months, $11.0 \mathrm{~mm}$ for autumn months, $7.7 \mathrm{~mm}$ for summer months and $11.3 \mathrm{~mm}$ for general average. The long-term maximum precipitation averages of Ürgüp are $13.4 \mathrm{~mm}$ for the spring months, $11.0 \mathrm{~mm}$ for the winter months, $10.8 \mathrm{~mm}$ for the autumn months, $7.5 \mathrm{~mm}$ for the summer months and the overall average is $10.7 \mathrm{~mm}$.

Considering the total precipitation values; Avanos long-term changes were recorded as $102.6 \mathrm{~mm}$ in spring, $96.1 \mathrm{~mm}$ in winter, $62.1 \mathrm{~mm}$ in autumn, $32.0 \mathrm{~mm}$ in summer and $292.8 \mathrm{~mm}$ in average for long years. The long-term changes of Nevsehir province were recorded as $130.3 \mathrm{~mm}$ in spring, $123.5 \mathrm{~mm}$ in winter, $71.6 \mathrm{~mm}$ in autumn, $37.5 \mathrm{~mm}$ in summer and $362.9 \mathrm{~mm}$ in average for long years. The long-term changes of Urgup were recorded as $123.2 \mathrm{~mm}$ in spring, $95.9 \mathrm{~mm}$ in winter, $74.5 \mathrm{~mm}$ in 
autumn, $33.4 \mathrm{~mm}$ in summer and $326.9 \mathrm{~mm}$ in average for long years. While an increasing trend was observed in all seasons based on maximum and minimum temperature changes, no increase was observed in the distribution of total precipitation values in terms of years in maximum precipitation in winter months only.

It has been concluded that precipitation changes in the provinces of Avanos, Ürgüp and Merkez for many years are increasing in the global climate change with increasingly negative changes in precipitation. Water, which is the source of life for all living things, is gradually decreasing and serious water crisis problems are expected to be at the door in the coming years. Gradually decreasing rainfalls due to climate changes endanger the living habitat. As a precaution, precise solutions are needed to reduce carbon dioxide in the air and slow down global warming and eventually end it. In this way, greenhouse effect and global warming can be prevented.

\section{REFERENCES}

1. Türkes M, Sümer UM, Demir I. Re-Evaluation of Trends and Changes in Mean, Maximum and Minimum Temperatures of Turkey for the Period 1929-1999. International Journal of Climatology, 2002: 22 (947-977).

2. Cosun F, Karabulut M. Kahramanmaraş'ta Ortalama, minimum ve Maksimum Sıcaklıkların Trend Analizi. Türk Coğrafya Dergisi, 2009: (53)41-50. (in tukish).

3. Kızılelma Y, Çelik MA, Karabulut M. İç Anadolu Bölgesinde sıcaklık ve yağışların trend analizi. Türk Coğrafya Dergisi, 2015: 64(1-10), İstanbul (in turkish).

4. Anonymous. Nevşehir Merkez İlçesi Meteoroloji İstasyonları sıcaklık değerleri, Meteoroloji Genel Müdürlüğü, Ankara. 2019. (in turkish)

5. Mann HB, Non-parametric Tests Against Trend. Econometrica, 1945: (13)245-259.

6. Kendall M G. Rank Correlation Methods. Charles Griffin, London, 1975:135.

7. Gümüs V, Yenigün K. Fırat Havzası Akımlarının Trend Analizi İle Değerlendirilmesi, Harran Üniversitesi Fen Bilimleri Enstitüsü İnşaat Mühendisliği Anabilim Dalı, Yüksek Lisans Tezi, 2006, Şanlıurfa (in turkish). 